\title{
Conditions for using of trams on railway tracks sections in agglomeration communication in Poland
}

\author{
Zbigniew Durzyński ${ }^{1, *}$, Marta Pachołek ${ }^{1}$, and Rafat Cichy ${ }^{1}$ \\ ${ }^{1}$ Rail Vehicle Institute “TABOR”, ul. Warszawska 181, 61-055, Poznań, Poland
}

\begin{abstract}
At the beginning the justification for searching for an effective, energy-efficient mass communication system in agglomerations in Poland are described. One way of relieving the density of the means of communication on the streets of Polish cities is to extend the offer of tram transport by the partial use of railway networks. The literature is reviewed for already implemented two-system tram-train systems and presented solutions for a such tram system in Europe. It is described the technical and organizational problems related to implement the tram-train vehicle in Poland. How-ever, it is important to overcome the formal barriers related to the authorization of vehicle for placing in tram and railway service (new technical standards for this type vehicle). In order to indicate the scope of technical problems, in the further part of this paper it is made the comparisons by analysing the current regulations and standards of basic requirements for tram and passenger railway vehicle. At the end of paper, alternative measures are proposed to introduce tramtrain vehicles. That will influence the attractiveness of public transport in urban agglomerations.
\end{abstract}

\section{Introduction}

For example, Fig. 1 shows levels of air pollution in Poznan in early 2017. Maintaining such a trend, which is pre-sent not only in Polish cities, will cause catastrophic climate change presented in Fig. 2, which may result in, for example, in the flooding of Venice by the year 2100.

In the described situations it is necessary to seek technical and organizational measures to limit urban car traffic as a result of developing more efficient public transport systems based on energy-efficient means of transport.

One such way is to increase the share of trams in transport in the urban agglomerations, also as a result of the partial use of railway infrastructure in agglomeration and metropolitan areas for tram traffic.

Such systems, called tram-train systems, have already been implemented in several European cities. This subject has already been discussed by specialists in various technical journals $[1 \div 7,10,14,17,20]$, but some aspects of this problem were discussed.

\section{Review of existing solutions for the use of dual-mode vehicles in public transport}

\subsection{Karlsruhe}

The most popular tram system is the tram in Karlsruhe, Germany [15]. Since September 25, 1992, the first time a Siemens dual-mode tram course took place in the city for the first time in the world. Over time, the dual-track tram route began to expand and in the end there were 12 dualmode tram lines with-in a radius of up to $70 \mathrm{~km}$ from the city centre, serving 190 stations. The Karlsruhe model is mainly based on the vehicle's ability to travel on lines of two different supply voltages: $15 \mathrm{kV} 162 / 3 \mathrm{~Hz}$ for rail and $750 \mathrm{~V}$ for tram. On urban roads, vehicles follow traditional tram traffic rules and on railways according to the DB rules. This solution uses already existing sections of railway lines. The introduction of the twin-track tramway in Karlsruhe has been successful, among other things, by the fact that the train station is about $2 \mathrm{~km}$ from the city centre. This change allowed people to reach the exact centre with-out having to switch to a tram [9].

\subsection{Zwickau}

The German city of Zwickau has adopted a completely different model of integration of the tram and rail system than Karlsruhe. In order to ensure smooth and uninterrupted commuter traffic to the city centre, it was decided to allow light rail vehicles on tramways. To make it possible, it was necessary to rebuild about one kilometre length of the track in order to allow vehicles wider than the trams to travel through. In addition, it was necessary to add a third rail to the track - the width of the tram tracks was $1000 \mathrm{~mm}$ and the rail was $1435 \mathrm{~mm}$. Additionally, the construction of tram tracks has been strengthened to with-stand higher loads. From the side of the rolling stock it was necessary to adapt it to the requirements of tram wagons, among others to equip the

\footnotetext{
* Corresponding author: z.durzynski@tabor.com.pl
} 


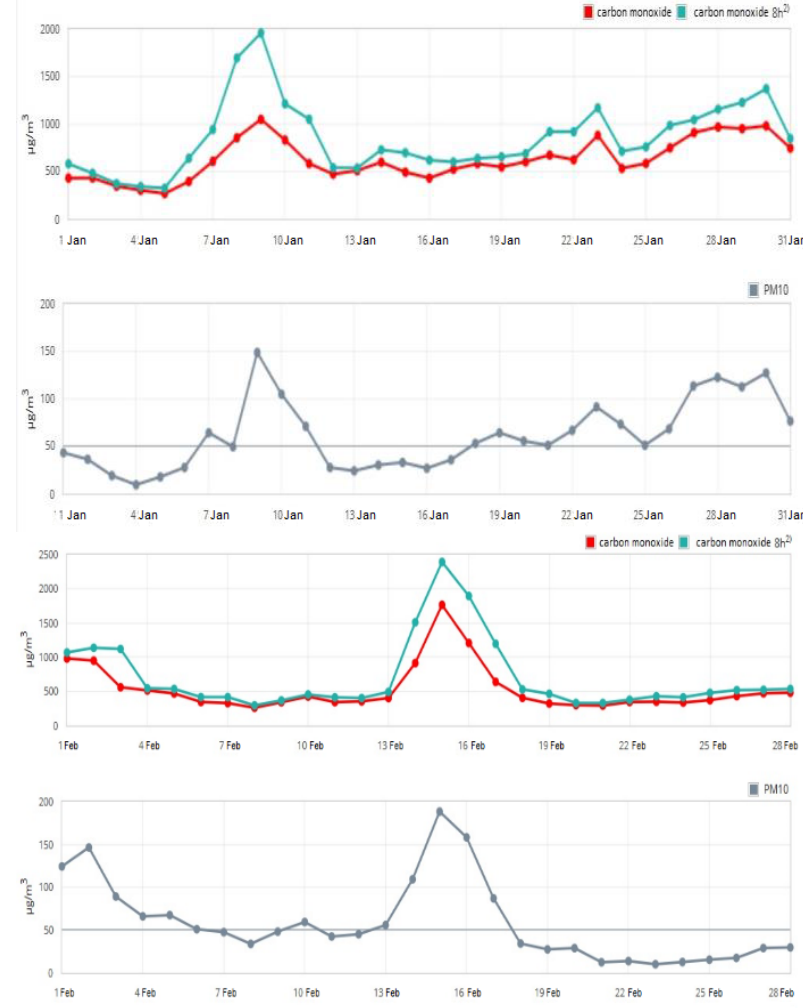

Fig. 1. Poznan air pollution data between 01-02.2017 (measurement: Polanka station) [12].

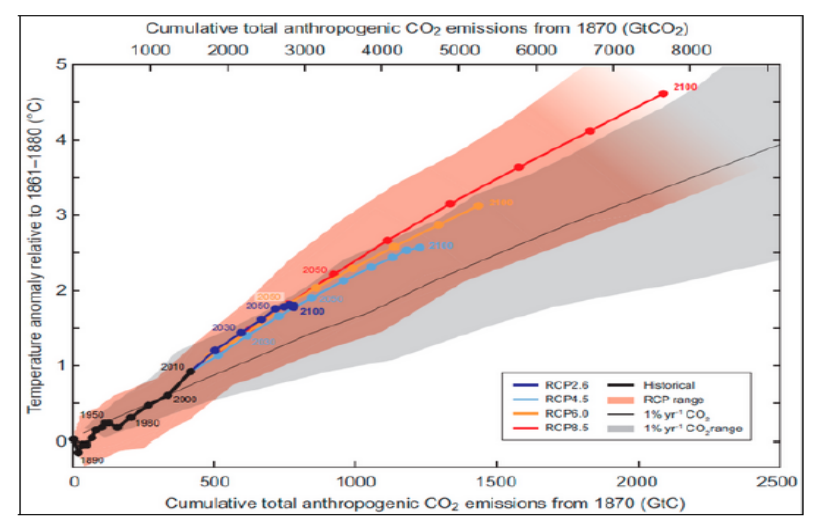

Fig. 2. Forecast of temperature increase due to global $\mathrm{CO}_{2}$ emissions [17].

direction indicators. But the most important difference in the solution introduced in Zwickau compared to Karlsruhe is the use of rolling stock in urban traffic. There was no need to adapt the vehicle to feed the various traction network voltages [16].

\subsection{Kassel}

Another city also in Germany, which effectively implemented two-system tram is Kassel. Two types of tram-way connections are used here. In the first case, it consisted of the modernization of the single-track approach from Kassel to Lichtenau used in the past to transport freight. This line was electrified with a tram voltage of $600 \mathrm{~V}$. The stops are equipped with so-called.
Additional track weights to make it possible to continue to operate the railway in this area. The second way to introduce trams to the railway was the introduction of two-system trams adapted to move on the tram and railway network. The supplier of such vehicles was Alstom, offering a RegioCitadis vehicle. Up to now, twosystem trams in Kassel serve four lines on a total length of $145 \mathrm{~km}$, but on the RT4 section, which has not been electrified, only hybrid-electric vehicles operate. Other lines support two-system vehicle solution with a $600 \mathrm{~V}$ power supply system for trams along a $15 \mathrm{kV}-162 / 3 \mathrm{~Hz}$ [18].

\subsection{Nordhausen}

The concept of a dual-mode tram was used in the Ger-man city of Nordhausen in a slightly different way, compared to Karlsruhe. In this case, the choice was a hybrid fleet equipped with an additional diesel engine used for travelling on the off-street traction. In addition, in order to make this connection between tram and rail infrastructure possible, it was necessary to build a link between the tram loop and the narrow-gauge railway station in 2002. Two more years have passed before the dual-mode tram line No. 10 to Ilfeld was launched. This line is $11 \mathrm{~km}$ long, and the time it takes to travel using a the two-system tram ranges be-tween 27 and 35 minutes. Three Siemens Combino Duo vehicles with a total capacity of 34 tonnes were purchased for this line. The vehicle has 27 seats and a capacity for additional 68 standing passengers. It moves at a maximum speed of $70 \mathrm{~km} / \mathrm{h}$ [11].

\subsection{France}

Not only German cities observe the trend in the use of railway lines for tram vehicles. France has followed the trend of its neighbors. In 2006 Ile de France launched the first dual track-tram system in France. A fragment of a closed railway linking Aulnay sous Bois and Bondy was used. Stops along the lines have been adapted to handle trams by mounting a passenger information system and ticket machines. Two-system trams were provided by Siemens. These trams are powered by $750 \mathrm{~V}$ for tram traction and $25 \mathrm{kV} 50 \mathrm{~Hz}$ for rail traction. Apart from adapting vehicles to these changes the city has decided to introduce a number of infrastructure improvements. One of them was to prioritize tramways on pedestrian crossings by using ap-propriate traffic lights and GPS devices. For pedestrians, a red light signalling on the STOP sign board was added and marking the nearest crossing with black and white chickened pattern [8].

\subsection{Others}

Apart from France and Germany, two-mode trams can be found in other European countries such as Italy, Spain, the Netherlands as well as North America. These systems are the most well-known models. Other solutions in other cities rely directly on these systems to match the infrastructure to their requirements $[10,11]$. 
The concept of building a two-system tram using the rail-road tracks to move trams also appeared in Poland. Such solutions have been considered in Wroclaw[10], Cracow [2, 3, 19], Gdańsk among others [13].

\section{Barriers to putting a tram on the railroad tracks}

\subsection{Technical difficulties}

\subsubsection{Different wheel and track profiles}

Different shape of the wheel rim and tilt of the rail. On the rail track, the tilt is 1:20 and 1:40 inward, while in the tram network the inclination is contained in the rail profile by the appropriate configuration of the rail head (the most commonly used rails are Ri60N, S49, LK1). In addition, the issue of track crossing is different. For trams, this takes place along the perimeter of the gently rising ramp inside the crossing groove - see Fig. 3. The crosses are done by passing the rim over the groove in the crossroads of rail-road tracks - see Fig 4. Possible solution is the selection and use of an intermediate wheel profile.

Dual-track trams can be extended with $135 \mathrm{~mm}$ wide rims, so it is necessary to raise the rail above the track base by $10-15 \mathrm{~mm}$ to avoid overriding the rail head and avoid contact of the extended wheel rim with the track. It would also be advisable to use rails with a groove depth of 45$47 \mathrm{~mm}$ and it would be impossible to run wheels on the rim in the event of significant vertical wear of the rails.

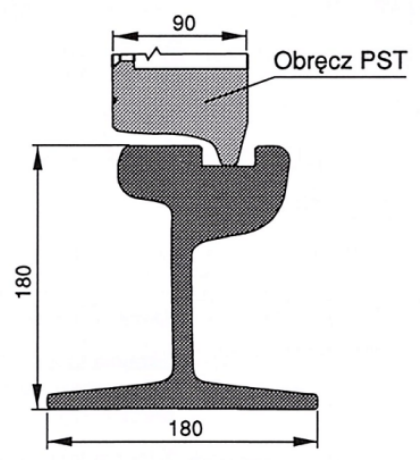

Fig. 3. Image of a tram wheel when crossing a switch or a tram intersection [4].

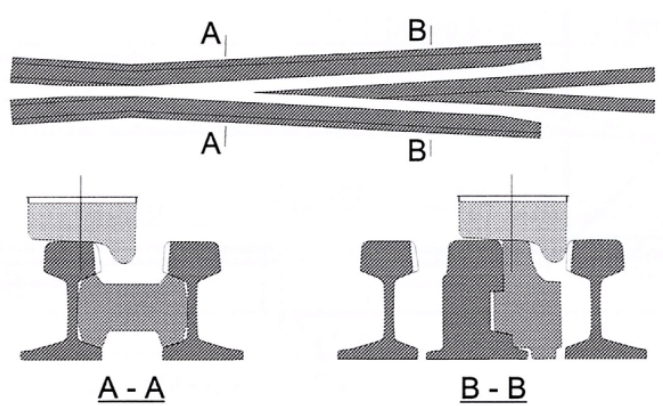

Fig. 4. Image of a rail wheel when crossing a switch [4].

\subsubsection{Expansion tolerances in arches}

The rail uses wooden sleepers to widen the rail track to ensure smooth passage through arches. The use of reinforced concrete reinforcements is not possible due to the unequivocal point of fixing the anchorage. For example, for an arc of less than $160 \mathrm{~m}$, the width can be as high as $25 \mathrm{~mm}$, giving a $1460 \mathrm{~mm}$ track spacing [11]. In contrast, in tram tracks there is no such widening, and the wheelbase tolerance is $\pm 2 \mathrm{~mm}$ on the straight and -0 and +4 on the bends (according to PN-K-92011:1998).

\subsubsection{Different drive system}

The electric railway traction voltage in Poland is $3 \mathrm{kV}$ and the tram system is $600 \mathrm{~V}$. It will be necessary to adjust the vehicle to operate using two voltages. Inverters and circuit switches must be used. This solution also requires adapting the infrastructure, which must have an electric traction section of the overhead contact line. An alternative to this solution is to equip the vehicle with an internal combustion engine. Then the vehicle could move on tram tracks using traction and train tracks using an internal combustion engine and vice versa.

\subsubsection{Different vehicle signalling and marking systems}

It is necessary to adapt the vehicle to two traffic systems. Trams must be equipped with, among others, direction indicators, which are not required for rail traffic. On the other hand, the light marking of a railway vehicle needs to be adapted to railway requirements, among others, to properly mark the beginning and end of the vehicle in signal lights.

\subsubsection{Durability in crash}

There are no specific Polish requirements for endurance and durability requirements for tram frames. Thus the vehicles will have to meet the railway requirements. Railway requirements for maximum thrust longitudinal force are contained in PN-EN 12663-1:2010+A1:2014 depending on vehicle category. For P II passenger vehicles (train-sets and coaches), this power is $1500 \mathrm{kN}$. Increasing the structural strength of the vehicle frame is directly related to the weight gain of the vehicle. A track can be traversed by a vehicle with a maximum axle load of $100 \mathrm{kN}$ at maxi-mum allowable tram weight.

\subsubsection{Different track gauge}

In Poland there is also a narrow gauge tram track width of $1000 \mathrm{~mm}$. If it is necessary to adapt such a track to a twosystem vehicle, it would be necessary to equip the track with a third rail (e.g. as it was done in Zwickau). In Poland, the narrow gauge tram tracks are found in Bydgoszcz, Torun, Elbląg, Łódź and Grudziądz. 


\subsubsection{Traffic control systems}

In the case of trams the signal is coupled with the street signal, while on the railway tracks the traffic is driven from the dashboard and is based on the line and station lock systems. The solution is to adapt the two-mode vehicle to railway and tramway standards (rail traffic control equipment). In addition, the vehicle would have to be equipped with traffic safety devices - active dead man's switch, SHP and radio.

\subsection{Organizational difficulties}

\subsubsection{Traffic intensity on the railway tracks and priority for the tram-train vehicle}

It would be troublesome to add extra journeys on routes with heavy traffic. For example, in Karlsruhe, tram traffic jams occur in the morning and in the afternoon, where the capacity of tram routes is insufficient and the vehicles cannot be extended due to the regulations in force (in Poland the maximum tram length can be $65 \mathrm{~m}$ ). All traffic control issues should be covered by appropriate instructions, regulations and internal PKP instructions. A two-system tram entering a railroad track would have to have a train number. There is also a large variation in the rules of tram and train traffic. Trams are driven using visibility - one behind the other, keeping a safe distance between each other. Trains, on the other hand, are managed on a "track section" basis, which means that only one vehicle can be pre-sent on a given section of the trail.

\subsubsection{Driver or motorman?}

The next organizational issue is the lack of coherence of traffic regulations on railway and tramway tracks. It will be necessary to train staff to navigate two types of roads. A person operating a two-mode vehicle on railway tracks should have a train driver's license with knowledge of rail traffic and traffic posts. On the other hand, a person running a tram in urban traffic should have the qualifications of a train operator. It will be easier to train drivers into operators due to the long duration of train drivers training. Alternatively, it is possible to make changes to the instructions on professional training of the PKP to include a provision on the two-system tram.

\subsubsection{Passenger information}

Adjustment of platform/tram stop information boards/passenger service (information boards showing waiting times for the nearest tram, ticket machines etc.). Introducing a uniform system of one time and periodical tickets valid for both rail and tram travel.

\subsection{Legal difficulties}

\subsubsection{Approval processes for the vehicle to train and tram exploitation}

In order for the vehicle to be able to move on tram tracks it must meet the conditions set out in the Regulation of the Minister of Infrastructure of 2nd of March 2011 on the technical conditions of trams and trolley-buses and the scope of their necessary equipment (Journal of Laws 2011 No. 65 item 344) and the Regulation of the Minister of Transport, Construction and Commerce of 28 May 2013, on type-approval of trams and trolleybuses (Journal of Laws 2015, item 38). On the other hand, a vehicle traveling on railway lines in Poland must obtain a permit from the Railway Transport Office for a free passage on railway tracks. This approval is granted on the basis of meeting the requirements set out in the Ordinance of the Minister of Infrastructure and Construction of 21 April 2017, on rail interoperability (Journal of Laws 2017, item 934) and related documents. These permits are made in two variants: TSI compliant or non TSI compliant. In the case of a vehicle conforming to the TSI and meeting the requirements specified therein, the authorized entity shall issue an EC Verification Certificate, under which the manufacturer creates an EC Declaration of Conformity. These two documents in turn are submitted to the Rail Transport Authority for authorization. In the case of a vehicle not compliant with the TSI, the requirements of standards and regulations published in the current Letter of the President of the UTK shall apply. Then, for a TSIcompliant part, the authorized body issues an EC Verification Certificate under which the manufacturer creates an EC Declaration of Conformity and for the nonTSI compliant entity the authorized body issues a Certificate of Conformity under which the manufacturer creates a Declaration of Conformity. On the basis of these documents, the Office of Rail Transport issues an indefinite permit.

\subsubsection{Introducing new normative legislation}

The implementation of the tram-train system in Poland will require the introduction of two coherent legislative systems for the design, construction and operation of rolling stock and infrastructure maintenance.

\section{Comparison of basic requirements for trams and passenger rail vehicles}

It is not possible to directly compare the requirements for tram and train traffic. These vehicles have completely different requirements backed by different standards and documents.

Examples of tests to be carried out to approve a vehicle (tram or train) for operation are:

- braking system tests;

- testing the acoustic properties;

- axle load testing;

- light and marking tests;

- tests of the combustible non-metallic materials used in the interior of the vehicle.

The approval requirements result from the documents listed in Table 1. 
Table 1. Documents containing requirements for the admission of the tram and train to service.

\begin{tabular}{|c|c|c|}
\hline Tram requirements & TSI conforming railway requirements & TSI non-compliant railway requirements \\
\hline \multicolumn{3}{|c|}{ Braking system } \\
\hline $\begin{array}{l}\text { Journal of Laws } 2011 \text { No. } 65 \text { pos. } 344 \text {; } \\
\S 16-18\end{array}$ & $\begin{array}{l}\text { TSI } 1302 / 2014 \text { from } 18.11 .2014 \text { and } \\
\text { related documents }\end{array}$ & $\begin{array}{l}\text { PN-EN 16452:2015-08, } \\
\text { PN-EN 14198:2005, } \\
\text { PN-EN 15734-1:2011, } \\
\text { UIC 540, UIC 541-03, } \\
\text { UIC 541-5, UIC 541-6, } \\
\text { UIC 544-2, UIC 546, } \\
\text { PN-K-88177:1998+Az1:2002 } \\
\text { PN-EN 16334:2014-10, } \\
\text { PN-EN 15612+A1:2011 } \\
\text { UIC 541-1, UIC 612-1 } \\
\text { UIC 544-1, UIC 543, } \\
\text { UIC 567-1, UIC 567-2, } \\
\text { PN-EN 14531-1:2016-02, } \\
\text { PN-EN 15595+A1:2011, }\end{array}$ \\
\hline \multicolumn{3}{|c|}{ Acoustic properties } \\
\hline $\begin{array}{l}\S 3 \text { pt. } 8 \text { and } \S 5 \text { pt. } 3 \text { Journal of Laws } \\
2011 \text { No. } 65 \text { pos. } 344\end{array}$ & $\begin{array}{l}\text { TSI } 1304 / 2014 \text { from } 26.11 .2014 \text { and } \\
\text { related documents }\end{array}$ & $\begin{array}{l}\text { PN-EN ISO 3095:2013-12, ANX TM-2 } \\
\text { PN-EN 15153-2:2013-06, UIC } 644 \\
\text { (sound signalling) }\end{array}$ \\
\hline \multicolumn{3}{|c|}{ Axle Loads } \\
\hline $\begin{array}{l}\S 3 \text { pt. } 5 \text { Journal of Laws. } 2011 \text { No. } 65 \\
\text { pos. } 344\end{array}$ & $\begin{array}{l}\text { TSI } 1299 / 2014 \text { from } 18.11 .2014 \text { and } \\
\text { related documents }\end{array}$ & PN-EN 14363:2016-04, ANX TM-1 \\
\hline \multicolumn{3}{|c|}{ Lighting and signalling } \\
\hline $\begin{array}{l}\text { Attachment } 2 \text { to Journal of Laws } 2011 \\
\text { No. } 65 \text { pos. } 344 \text {. }\end{array}$ & $\begin{array}{l}\text { TSI } 1302 / 2014 \text { from } 18.11 .2014 \text { and } \\
\text { related documents }\end{array}$ & $\begin{array}{l}\text { PN-EN 15153-1:2013-06 } \\
\text { PN-EN 13272:2012 } \\
\text { UIC 534 }\end{array}$ \\
\hline \multicolumn{3}{|c|}{ Properties of combustible non-metallic materials used in the vehicle interior } \\
\hline PN-K-02511:2000 & $\begin{array}{l}\text { TSI 1302/2014 from } 18.11 .2014 \text { and } \\
\text { related documents }\end{array}$ & PN-EN 45545-2+A1:2015-12 \\
\hline \multicolumn{3}{|c|}{ Loading gauge } \\
\hline PN-K-92008:1998/Ap1:1999 & $\begin{array}{l}\text { TSI } 1302 / 2014 \text { from } 18.11 .2014 \text { and } \\
\text { related documents }\end{array}$ & $\begin{array}{l}\text { PN-EN } 14033 \text { (series), } \\
\text { PN-EN 15273-2:2013-09, PN-EN } 15746 \\
\text { (series), } \\
\text { UIC 505-1, UIC 505-6, } \\
\text { UIC 506, } \\
\text { Regulation on the operation of railway } \\
\text { vehicles (see Annex A-1); } \$ 4\end{array}$ \\
\hline
\end{tabular}

\section{Legal barriers arising from the provisions on the use of railway infrastructure}

\subsection{Adjusting the height of the floor in a two- system vehicle to the edge height of the platform}

The height of the tram platforms is smaller than the typical railway platforms. The possible solution is to rebuild the infrastructure or adapt the vehicle to the existing railway platforms by adding a deployable step. These elements should automatically hide when closing the door.

\subsection{Rolling stock gauge - distance from the platforms}

According to the tram regulations (Journal of Laws 2011 No. 65 item 344) the maximum width of the tram can be $2.65 \mathrm{~m}$ without mirrors (e.g. RegioCitadis manufactured by Alstom). It generates a problem of bigger distance between tram and platform. The solution is to adjust the existing infrastructure by reconstructing platforms or using the so-called track splices, or platforms adapted to handle two types of vehicles, each on a different platform side. This solution allows to use the stops by the classic tram by driving up to the very edge of the platform. In case it is not possible to rebuild the infrastructure, as in the case of different platform heights, a retractable ladder or ramp can be used. This will not only reduce the height difference, but also reduce the distance between the door and the distant platform.

\section{Suggestions for alternative solutions for agglomeration communication by using trams}

\subsection{Park\&Ride}

An alternative method of reducing the load on public transport, without investing in new rolling stock and railway infrastructure, is to build park \& ride parking spaces at tram or bus loops. This would allow a significant relief of traffic flows in the centre of cities. This solution is justified in cases where the suburban network is not significantly expanded and the frequency of interstate calls is not high. The idea of the park and ride system is to reach the city's outskirts by private transport and change to public transport for in city commute. This 
arrangement should include an estimate of the size of the car parks based on local conditions. These parking lots should be equipped not only with parking spaces for cars, but equally important is the provision of bike space.

\subsection{Bus lanes}

The designation of urban lanes for public transport buses will streamline bus journeys through the often crowded streets. This will allow the shortening of the passenger travel time by means of transport making it more competitive. Moreover, thanks to such a solution, it would be possible to move from the suburban areas quickly and without vehicle changes to reach the city centre. In the case where it is not possible to drive a separate bus lane in the centre of the city, a separate tramway track can be used (as far as its construction permits it) and treated as a bus and tram lane. It is also important to establish a priority system for bus crossings with traffic lights.

\subsection{Railway ring}

An alternative to the creation or adjustment of railway tracks for two-system trams is the creation of a perimeter railway ring, as it was done in the city of Ringbahn in Berlin. This railway bypass is designed to connect public transport lines (e.g. tram, metro) located on the outskirts of the city and downtown directly with inner city lines. In addition, it will allow for bypassing the city by freight trains.

\section{Summary}

It is undeniable that the development of public transport in agglomerations and metropolises is a necessity. To that end, all technically and economically viable means should be used. One of them is the use of the existing tram infrastructure in large cities in Poland, as has been done in some Western European countries. The favourable circumstance in most cases is the same track width of $1435 \mathrm{~mm}$ and level of development of power electronics, enabling the traction drive to be adjusted to different voltage levels. Admission of the tram to the railway tracks requires several construction projects, described above. However, it is important to overcome formal barriers related to the admission of a vehicle to rail and tram traffic, requiring the development and establishment of new technical standards for a tram-train vehicle. Railway Transport Office and Trans-port Technical Supervision will be involved in this stage, supported by experts from authorized scientific and rese-arch units.

\section{References}

1. T. Czauderna, Próbne jazdy wagonu tramwajowego 105NT po torach kolejowych. TTS 7-8 (1998)

2. W. Czyczuła, Koncepcja zintegrowanego systemu transportu szynowego dla Krakowa. TTS 9 (1999)
3. W. Czyczuła, Koncepcja zintegrowanego systemu transportu zbiorowego dla Krakowa - dlaczego tramwaj dwusystemowy? TTS 1-2 (2000).

4. W. Czyczuła, Warunki techniczne jakim powinna odpowiadać infrastruktura kolejowa i tramwajowa ze względu na ruch pojazdów dwusystemowych. TTS 1-2 (2000)

5. W. Czyczuła, J. Raczyński, Pojazd dwusystemowy jako środek transportu regionalnego. TTS 11 (2000)

6. J. Dąbrowski, Dwusystemowe tramwaje - czyli tramwaj na torach kolejowych. TTS 7-8 (1998)

7. J. Dąbrowski, Rozważania nad koncepcja napędu tramwaju dwusystemowego $w$ warunkach polskich. TTS 9 (1999)

8. A. Drapała, Pierwszy tramwaj dwusystemowy we Francji. Transport miejski i regionalny 2 (2007)

9. G. Drechsler, Light railway on conventional railway tracks in Karlsruhe, Germany. Proceedings of the Institution of Civil Engineers - Transport Volume 117 Issue 2 (1996)

10. I. Gisterek, M. Krużyński, Ocena możliwości $i$ zasadności uruchomienia tramwaju dwusystemowego we Wrocławiu. Transport miejski i regionalny 11 (2010)

11. A. Harassek, Dwusystemowy tramwaj w Nordhausen. TTS 6 (2004)

12. https://powietrze.poznan.wios.gov.pl/

13. http://warszawa.naszemiasto.pl/artykul/w-gdanskutramwaje-beda-jezdzic-po-torachkolejowych,16915,art,t,id,tm.html

14. C. Kraśkiewicz, W. Oleksiewicz W, Tramwaj dwusystemowy - moda czy trend rozwojowy aglomeracyjnego transportu szynowego? Logistyka nr 4 (2015)

15. C. Kraśkiewicz, W. Oleksiewicz, Tramwaj dwusystemowy w Karlsruhe. Logistyka 4 (2015)

16. C. Kraśkiewicz, W. Oleksiewicz, Tramwaje dwusystemowe $w$ wybranych miastach niemieckich. TTS 12 (2016)

17. I. Merkisz, P. Lijewski, P. Fuć, J. Pielecha, Exhaust emission tests from agricultural machinery under real operating conditions. SAE 2010 Commercial Vehicle Engineering Congress, (SAE Paper 2010)

18. Ch. Muller, RegioTram Kassel. ElEisenbahnigenieur 7/2006 (2006)

19. W. Wańkowicz, Zagadnienia formalnoprawne a dwusystemowy Krakowski Szybki Tramwaj. TTS 1$2(2000)$

20. I. Wieczorek, Problemy eksploatacyjno-ruchowe związane $z$ wprowadzeniem pojazdów dwusystemowych na sieć PKP. TTS 1-2 (2000) 